\title{
Description and Economic Evaluation of a "Zero-Waste Mortar-Producing Process" for Municipal Solid Waste Management in Greece
}

\author{
Alexandros Sikalidis ${ }^{1,2}$ and Christina Emmanouil ${ }^{3, *}$ \\ 1 Amsterdam Business School, Accounting Section, University of Amsterdam, \\ 1012 WX Amsterdam, The Netherlands \\ 2 Faculty of Economics, Business and Legal Studies, International Hellenic University, \\ 57001 Thessaloniki, Greece \\ 3 School of Spatial Planning and Development, Aristotle University of Thessaloniki, \\ 54124 Thessaloniki, Greece \\ * Correspondence: chemmanouil@plandevel.auth.gr; Tel.: +30-2310-995638
}

Received: 2 July 2019; Accepted: 19 July 2019; Published: 23 July 2019

\begin{abstract}
The constant increase of municipal solid wastes (MSW) as well as their daily management pose a major challenge to European countries. A significant percentage of MSW originates from household activities. In this study we calculate the costs of setting up and running a zero-waste mortar-producing (ZWMP) process utilizing MSW in Northern Greece. The process is based on a thermal co-processing of properly dried and processed MSW with raw materials (limestone, clay materials, silicates and iron oxides) needed for the production of clinker and consequently of mortar in accordance with the Greek Patent 1003333, which has been proven to be an environmentally friendly process. According to our estimations, the amount of MSW generated in Central Macedonia, Western Macedonia and Eastern Macedonia and Thrace regions, which is conservatively estimated at $1,270,000 \mathrm{t} / \mathrm{y}$ for the year 2020 if recycling schemes in Greece are not greatly ameliorated, may sustain six ZWMP plants while offering considerable environmental benefits. This work can be applied to many cities and areas, especially when their population generates MSW at the level of 200,000 t/y, hence requiring one ZWMP plant for processing.
\end{abstract}

Keywords: municipal solid waste management; economics; zero waste with mortar production method; Northern Greece

\section{Introduction}

Improved waste management is a key element in efforts towards achieving a resource-efficient Europe. Waste management principles are nowadays substantiated in the European Commission's "Roadmap on a resource efficient Europe" [1] as well as in the EU Waste Framework Directive [2]. In the directive, municipal waste (MSW) defined as "waste from households, as well as other waste which, because of its nature or composition, is similar to waste from households" [3] enjoys a prominent position in all waste management schemes, since it comprises the main bulk of waste that should be managed daily. Its contemporary management hierarchy, as laid out in Article 4 of the revised Waste Framework Directive [2], dictates a legally binding prioritization of waste management alternatives with prevention of MSW generation being prioritized and promoted, and disposal (mainly as landfilling) being least prioritized. As such, prevention (of waste generation) is considered the top priority, followed in descending order by (processes of) re-use, recycling, energy and raw materials recovery and finally disposal (in the form of landfilling) [4]. Out of these processes, waste disposal is recognized as the most harmful one from an environmental viewpoint, and as such it should be 
carefully designed and applied. When all reuse and recycling potential of the waste is depleted, recuperation of the materials found in waste and exploitation of its energy reserves becomes the next priority. This in turn completely changes the notion of the undesired end-of-life product or by-product, which is transformed into a valuable product (e.g., as proven in the case of municipal sludge by [5]). Furthermore, transformation of waste into a product (e.g., as a building material, as described here) substantiates social responsibility initiatives for construction companies as a way of characterizing the company's commitment to sustainability.

MSW in Greece is a diverse mixture of refuse comprising organic waste, plastics, metal, paper, hazardous and biohazardous components and inert materials among others [6]. Recycling of plastic, paper, aluminum, other metals and glass, usually without pre-separation, has systematically taken place in Greece since 2001 (the "blue bin" scheme) [7]. This scheme in 2018 served 10.3 million inhabitants and engaged 35 Recycling Sorting Centers [8]. Furthermore, a separate system for glass only has been put into practice since 2013 [8]. Additional recycling schemes for specialized waste (spent batteries, waste of electric and electronic equipment, used cooking oil, car parts, fluorescent lamps, etc.) also exist but they are not relevant for the present research. Much more can be done for recycling in Greece, especially in the aspects of education and sensitization of the public [9]. In addition, environmental performance of household waste management based on the Life Cycle Approach for Greece shows that there is room for improvement for recycling management in comparison to six other EU countries [10]. In general, municipal waste may be managed via land filling, recycling, composting, incineration, pyrolysis and thermal treatment for energy recovery, however, all of these processes pose a number of environmental concerns [11,12]. MSW contains combustible matter to a significant degree, thus energy recovery by its thermal processing is feasible. Its incineration at high temperature $\left(1450^{\circ} \mathrm{C}\right)$ produces ash that contains mineral matter. This ash can be mixed with the appropriate ingredients for clinker formulation for mortar production. Ash from MSW incineration for cement production has been the core topic for numerous publications and relevant patents; as such, [13] manufactured durable bricks from the municipal solid waste incinerator's fine ash and cement, and [14,15] produced cement-based mixtures from MSW fly ash and Portland cement at an optimum ratio of ash/cement. As such, residues of municipal waste are commonly incorporated in cement production through co-incineration [16]. Nevertheless, health and environmental risks arising from the incorporation of various wastes (formation of noxious by-products; see also [17] or pollutant leaching; see also $[18,19])$ should always be addressed. In the present work, the application of the Greek patent No. 1003333 [20], for a Zero Waste with Mortar Production (ZWMP) method, with demonstrated feasibility [21], is examined from an economic point of view for the management of MSW in Northern Greece and hence to other similar prefectures in the European Union. This application, which is characterized by minimal noxious emissions [21], may aid the reduction of GHG emissions in relation to the current landfilling Greek practice [22] and may improve the performance of the country in the LCA Characterization factors "Global Warming", "Marine Eutrophication", "Terrestrial Eutrophication", "(non-carcinogenic) Human Toxicity" and "Eco-toxicity", which is currently low, directly attributed to extensive landfilling [10]. At the same time, it can produce valuable goods at very competitive prices from waste material.

\section{State of the Art}

\subsection{MSW Production and Overall Management in Greece}

MSW management is a grave issue in Greece that affects both environmental quality and public health [23]. Integrated solid waste management requires continuous social intervention, up to date technical facilities and application of the best social and techno-economical methods available.

MSW in Greece is mostly landfilled, and this is associated with a series of environmental issues and concerns. Nowadays there is a lack of available landfill sites in Greece which has subsequently led to their increasing operational costs and the inelastic need to decrease the volume of MSW in landfills. 
The MSW production in Greece increased to $498 \mathrm{~kg}$ per capita (data of 2016), higher than the EU-28 average value of $483 \mathrm{~kg}$ per capita [24].

The average composition of MSW in Greece is: organics $44.3 \%$, paper $22.2 \%$, plastics $13.9 \%$, glass $4.3 \%$, metal $3.9 \%$, others $11.4 \%$ [25].

In Greece no incineration of MSW takes place [26], and it is not a top priority in the current national and regional MSW management plans (see also [27]), whereas incineration of hazardous and of non-hazardous medicinal waste and of sludge from wastewater treatment plants does take place (approximately 160,000 t/y, data of 2014) in Greece [28].

According to [24] there were 79 operational and functioning sanitary landfills with varied life durations in 2014. Furthermore, there is an increasing number of plants for mechanical recycling and composting and for biogas and energy production. A number of unauthorized landfill sites are still present and are going to be gradually paused (69 sites, data of 2014). 94 unauthorized landfills have been fully restored while the remaining 202 are in the process of remediation (data of 2014).

\subsection{MSW Production in Northern Greece}

Waste management activities are carried out by the Waste Management Authority of each administrative area. Northern Greece is comprised of three regions: The Central Macedonia Region, the Western Macedonia Region and the Eastern Macedonia and Thrace Region.

\subsubsection{MSW Production and Management in Central Macedonia Region}

In Table 1, MSW production, its future projection and MSW composition are presented for the Central Macedonia Region.

Table 1. Municipal solid wastes (MSW) production, projection and composition* in Central Macedonia region (data for 2014) (data compiled and derived from [29]).

\begin{tabular}{ccccc}
\hline \multicolumn{2}{c}{ Production $^{\mathbf{1}}$} & \multicolumn{3}{c}{ Evolution of Production $^{2}$} \\
\hline Prefecture & Metric Tons (t) & Year & Best-Case Scenario & Worst-Case Scenario $^{2}$ \\
\hline Chalkidiki & 63,124 & 2016 & 852,610 & $1,065,762$ \\
Serres & 53,898 & 2018 & 862,863 & $1,078,579$ \\
Pieria & 51,124 & 2020 & 873,256 & $1,091,570$ \\
\hline Thessaloniki & 407,717 & & & \\
Pella & 43,134 & & & \\
Imathia & 44,262 & & & \\
Kilkis & 31,613 & & & \\
Total & 694,873 & & & \\
\hline
\end{tabular}

\footnotetext{
1 production based on the weight of MSW deposited to sanitary landfill; recycled waste, including Waste of Electrical and Electronic Equipment, composted organics, batteries, mixed municipal recycling bins, is already subtracted. ${ }^{2}$ evolution based on population changes from Hellenic Statistical Authority (2001-2011) including touristic population, a GDP increase of $0.95 \% / y$, an MSW increase of half of the GDP (worst-case scenario) or an MSW increase of $0.38 \%$ incorporating a waste minimization plan (best-case scenario). ${ }^{*}$ Composition of MSW (based on national means due to non-reliable regional data): organics $44.3 \%$, paper $22.2 \%$, metal $3.9 \%$, plastic $13.1 \%$, glass $4.3 \%$, other $11.4 \%$.
}

The MSW management in the region is currently performed at the following establishments according to the latest Regional Waste Management Plan [29] (Figure 1): 11 sanitary landfills (SL) (Kilkis, Mavrorachi, Almopia, Palaiokastro, Katerini, Litochoro, Kassandra, Edessa, Giannitsa, Anthemous, Polygyros), five transhipment stations (TS), seven recyclables sorting centers (RSCs) (Thermi, Ionios, Kallithea, Sindos, Tagarades, Katerini, Serres), one rehabilitated waste disposal site (WDS) in Tagarades with one waste leachate treatment plant and one MSW electricity production plant that utilizes biogas. Seventy more WDSs are in the process of rehabilitation. Additional transhipment stations (14) and an integrated mechanical/biological/recyclable sorting facility and sanitary landfill in Serres are envisaged in the Management Plan [29]. As far as recycling is concerned, the national "blue bin" recycling scheme is also applied; in the blue bin paper, (clean) plastic, aluminum, glass are discarded. An additional 
separate glass-only bin is also in force with the exception of Kilkis prefecture. In 2014, approximately 9.2\% (w/w) of produced MSW were recycled through RSCs for Thessaloniki, $7.1 \%$ for Imathia, $5 \%$ for Kilkis, $10.8 \%$ for Pella, $7 \%$ for Pieria, $12.8 \%$ for Serres and 5\% for Chalkidiki. This performance was significantly improved if recycling material collected directly from market and industrial establishments was included. The residual fraction of recycled material after the separation phase in RSCs is quite high (31.9-42.2\%) for 2014 and it is also subsequently landfilled. No separate collection for biowaste is performed on a large scale except for Thessaloniki where modest house composting takes place [29].

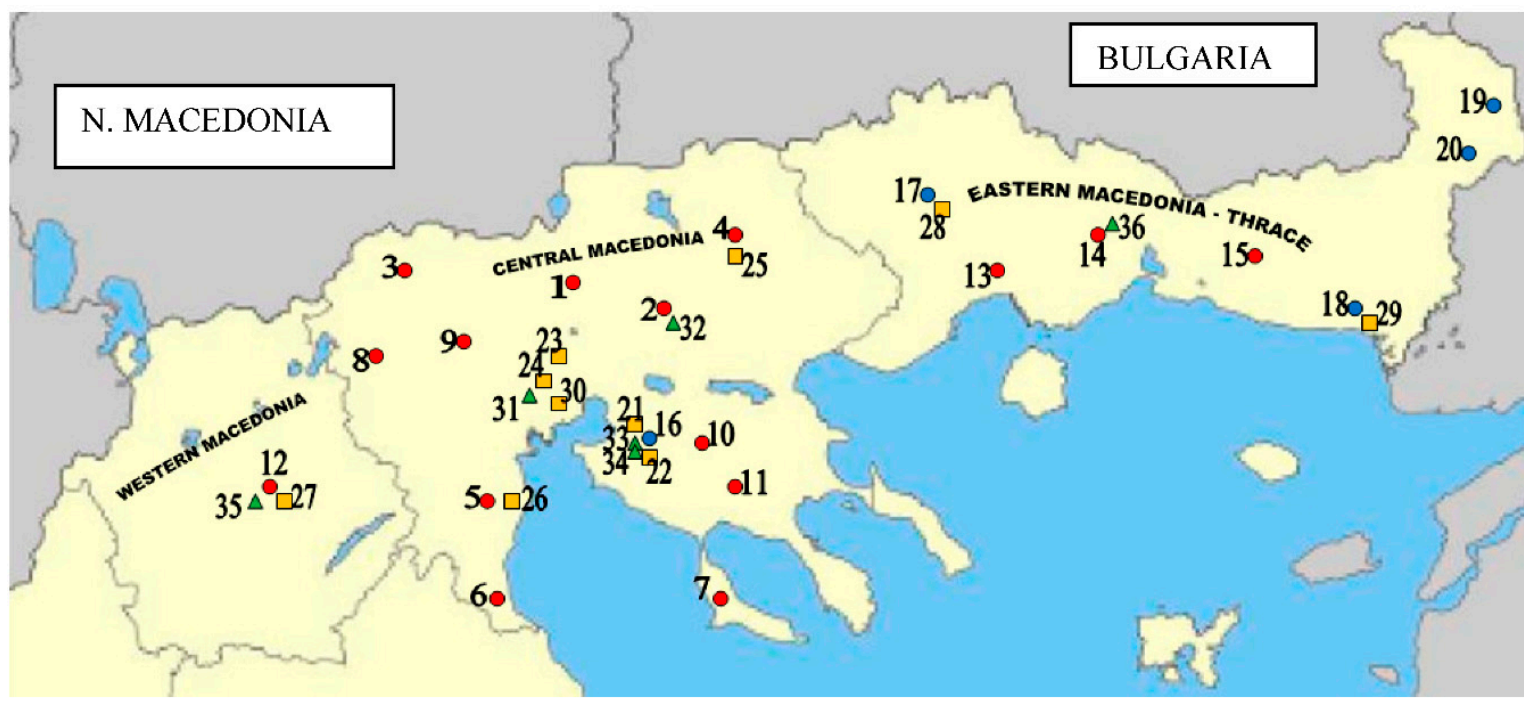

$\begin{array}{ll}\text { SL } & \text { SL } \\ \text { 1 Kilkis } & \text { 10 Anthemous } \\ \text { 2 Mavrorachi } & \text { 11 Polygyros } \\ \text { 3 Almopia } & \text { 12 Kozani } \\ \text { 4 Palaiokastro } & \text { 13 Kavala } \\ \text { 5 Katerini } & 14 \text { Xanthi } \\ \text { 6 Litochoro } & \text { 15 Komotini }\end{array}$

7 Kassandra

8 Edessa

9 Giannitsa

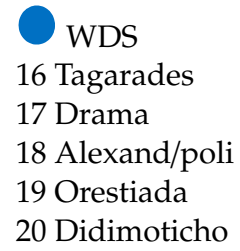

$\square$ RSC
21 Thermi
22 Tagarades
23 Kallithea
24 Ionia
25 Serres
26 Katerini

27 Kozani

28 Drama

29 Alexandroupoli

30 Sindos

Figure 1. Proposed distribution of sanitary landfills (SL), waste disposal sites (WDS), recyclable sorting centers (RSC) and zero-waste mortar production (ZWMP) plants in Northern Greece.

\subsubsection{MSW Production and Management in Western Macedonia Region}

In Table 2, MSW production, its future projection and MSW composition are presented for the Western Macedonia Region.

The MSW management in this region is currently performed at the following establishments according to the latest Regional Waste Management Plan [30] (Figure 1): One SL (Kozani), 10 TS and one RSC (Kozani). Various recycling schemes throughout the region and an integrated mechanical/biological/recyclable sorting facility in the proximity of the SL in Kozani are envisaged in the Plan [30]. As far as recycling is concerned, the national "blue bin" recycling scheme is applied; the glass-only blue bin and the paper-only collection system were nascent in 2014 with only 115 and 1000 collection points, respectively, for the whole prefecture. In 2015 , approximately $5.2 \%(w / w)$ of 
produced MSW were recycled through RSCs. This performance was significantly improved if an additional percentage of $6.6 \%(w / w)$, collected directly from market and industrial establishments, was included. The residual fraction of recycled material after the separation phase in RSCs is quite high $(30 \%)$ for 2014 and it is also subsequently landfilled. No separate collection for biowaste is performed on a large scale [30].

Table 2. MSW production, projection and composition * in Western Macedonia region (data for 2015) (data compiled and derived from [30]).

\begin{tabular}{|c|c|c|c|c|}
\hline \multicolumn{2}{|c|}{ Production ${ }^{1}$} & \multicolumn{3}{|c|}{ Evolution of Production ${ }^{2}$} \\
\hline Region & Metric Tons (t) & Year & Best-Case Scenario & Worst-Case Scenario \\
\hline \multirow{3}{*}{$\begin{array}{c}\text { Western } \\
\text { Macedonia }\end{array}$} & \multirow{3}{*}{99115} & 2016 & 104,298 & 104,298 \\
\hline & & 2018 & 105,827 & 107,366 \\
\hline & & 2020 & 107,377 & 110,524 \\
\hline
\end{tabular}

1 production based on the weight of MSW deposited to sanitary landfill; recycled waste including WEEE, composted organics, reused oils, batteries, mixed municipal recycling bins is already subtracted. Industrial/commercial waste is already subtracted. ${ }^{2}$ evolution based on population changes: A stagnant population until 2020 and a conservative MSW increase of $1.46 \%$ /person $\times$ year (worst-case scenario) or a conservative MSW increase of $0.73 \% /$ person $\times$ year (worst-case scenario). The changes (increases) in industrial/commercial waste are not relevant for these scenarios. * composition of MSW (based on regional data after subtracting mixed municipal recycling bins and industrial/commercial waste): organics $42.8 \%$, paper $23.45 \%$, metal $2.3 \%$, plastic $14.5 \%$, glass $2.8 \%$, leather-wood $4.3 \%$, other $9.35 \%$.

\subsubsection{MSW Production and Management in Eastern Macedonia and Thrace Region}

In Table 3, MSW production, its future projection and MSW composition are presented for Eastern Macedonia and Thrace Region.

Table 3. MSW Production, projection and composition* in Eastern Macedonia and Thrace Region (data for 2015) (data compiled and derived from [31,32]).

\begin{tabular}{cccc}
\hline \multicolumn{2}{c}{ Production $^{\mathbf{1}}$} & \multicolumn{2}{c}{ Evolution of Production $^{\mathbf{2}}$} \\
\hline Prefecture & Metric Tons (t) & Year & Most likely Scenario \\
\hline Evros & 51,156 & 2016 & 238,537 \\
Xanthi & 36,571 & 2018 & 245,554 \\
\hline Rodopi & 32,768 & 2020 & 252,776 \\
Kavala & 45,157 & & $280,000^{3}$ \\
\hline Drama & 34,203 & & \\
Total & 199,885 & &
\end{tabular}

\footnotetext{
${ }^{1}$ production based on the weight of MSW deposited to sanitary landfill; recycled waste including WEEE, composted organics, reused oils, batteries, mixed municipal recycling bins is already subtracted. Industrial/commercial waste is already subtracted. ${ }^{2}$ evolution based on population changes from Hellenic Statistical Authority (2001-2011) and an MSW increase of $1.46 \% / y$ according to European Topic Centre on Sustainable Production and Consumption. ${ }^{3}$ based on graphical extrapolation from [31]. * composition of MSW (based on regional data after subtracting mixed municipal recycling bins and industrial/commercial waste): organics $45.8 \%$, paper $15.3 \%$, metal $3.4 \%$, plastic $16.5 \%$, glass $4.3 \%$, wood $6.0 \%$, other $8.7 \%$.
}

The MSW management in this region is currently performed at the following establishments according to the latest Regional Waste Management Plan [32] (Figure 1): Three SL (Kavala, Xanthi, Komotini), six rehabilitated WDSs, five RSCs (Drama, Komotini, Xanthi, Alexandroupoli, Didymoteicho) and 13 TS. Various recycling schemes throughout the region, additional SL (Alexandroupoli, Samothraki, Thasos, Evros) and three large integrated mechanical/biological/recyclable sorting facilities (Kavala, Alexandroupoli, Evros) are envisaged in the Plan [32]. For the time being (2015), as far as recycling is concerned, the national "blue bin" recycling scheme is applied, and the glass-only bin is applied with 500 bins for the whole prefecture. In 2015, approximately $4 \%(w / w)$ of produced MSW were recycled through RSCs for Evros, $6 \%$ for 
Rodopi, 2.5\% for Xanthi, 2\% for Kavala and 5.3\% for Drama. This performance was significantly improved if recycling material collected directly from market and industrial establishments was included. No separate collection for biowaste is performed on a large scale, but it is envisaged soon [32].

\section{Materials and Methods}

\subsection{Short Description of the ZWMP (Zero Waste with Mortar Production) Method}

The ZWMP method has been officially patented under Greek law [20] and has been described in detail elsewhere [21]. In brief, heavy and large metal objects are manually subtracted from the bulk of MSW. The remaining metals also undergo magnetic separation, and the residues then undergo shredding, drying and secondary shredding to a final size of $0-15 \mathrm{~mm}$. MSW composition that is applicable for this kind of treatment may vary, and samples from large Greek cities that were considered appropriate for the method contained high organic fraction and lower percentages of metal and glass. After shredding, the material is dried in a rotary drier using flue gases from the rotary kiln at $180-200^{\circ} \mathrm{C}$, in absence of $\mathrm{O}_{2}$. As such, the residues are separated there to a 'heavy' fraction and a 'light' fraction. The heavy fraction is directly introduced in a specially designed dual-stage rotary kiln at $1100{ }^{\circ} \mathrm{C}$ together with a homogeneous mixture of limestone, clayey material, silicates and iron oxides $(30 \%$ residue on 170 mesh sieve). The overall mixture is obtained by thermal treatment in the rotary kiln at $1450{ }^{\circ} \mathrm{C}$. The light fraction, since it is combustible, is mixed added to pet-coke and burned for heating the rotary kiln. In order to improve its hydraulic properties, the produced clinker is finally milled together with gypsum. It is generally acknowledged that dioxins are formed during waste incineration due to $\mathrm{O}_{2}$ excess, presence of chlorine and metals in the fly ash and the favorable temperature of formation in the range of $250-400{ }^{\circ} \mathrm{C}[27,28]$. Dioxin and furan emissions are minimal in the ZWMP method, contributing to the minimization of dioxin and furan emissions, since the MSW are treated in dual-stage rotary kiln, which maintains a high temperature of $1100{ }^{\circ} \mathrm{C}$, which is well above the critical temperature of $400{ }^{\circ} \mathrm{C}$ of dioxin decomposition [21]. Nevertheless, provisions for an emissions control system are taken, and they contain (1) recycling of flue gas, (2) use of secondary air and (3) careful control of combustion conditions $[11,21,33]$.

\subsection{Economic Evaluation and Management of MSW through ZWMP Method in North Greece}

According to [21], building up and operating a plant that treats $\sim 500 \mathrm{t}$ MSW/day and thus produces $\sim 433 \mathrm{t} /$ day of mortar can achieve an economic profit. The scenario that follows is based on the estimation. There are specific quantities of raw ingredients necessary for the manufacture of arbitrarily $500 \mathrm{t}$ mortar/day as described on the Greek Patent No. 1003333. Based on this production, quantities of the rest of the materials are given in Table 4 taking into account that the ash content, in percent, of the MSW is $20 \% w / w$ [21]. For the data attributed to the year 2020, quantities of ash and of subsequent mortar that can be produced in each region are given in Table 5 .

Table 4. Raw materials in tones for daily mortar production [21].

\begin{tabular}{lcc}
\hline Raw Material & $\boldsymbol{\%} \boldsymbol{w} / \boldsymbol{w}$ & T Material/Day for $\mathbf{5 0 0} \mathbf{t}$ Mortar \\
\hline Limestone & 65 & 463.00 \\
Clayey material & 13 & 92.60 \\
Silicates & 2 & 14.25 \\
Iron oxides & 3 & 21.40 \\
Ash & 14 & 100.00 \\
Gypsum & 3 & 21.35 \\
Total & 100 & $712.60 *$ \\
\hline
\end{tabular}

${ }^{*}$ Reduction to $\sim 500 \mathrm{t}$ due to weight loss after thermal treatment of raw materials. 
Table 5. Quantities of ash and mortar that can be produced in ZWMP plants from MSW per region of Northern Greece.

\begin{tabular}{lcccc}
\hline \multicolumn{1}{c}{ Region } & MSW Production (t/y) & Ash (t/y) * & Ash (t/d) & Mortar (t/d) ** \\
\hline Central Macedonia & 873,256 & $174,651.2$ & 499.0 & 2945.0 \\
Western Macedonia & 107,377 & $21,468.8$ & 61.3 & 306.5 \\
Eastern Macedonia and Thrace & 252,776 & $50,555.2$ & 144.4 & 722.0 \\
\hline
\end{tabular}

${ }^{*}$ based on $20 \%$ ash content in MSW, ${ }^{* *}$ based on 5:1 mortar/ash ratio.

As a second step, locations of the possible ZWMP plants were established based on the following criteria: (a) the distance from important SL sites; (b) the ranking capacity of SL sites; (c) the minimum distance from main cities permitted; (d) the environmental issues, such as the distance from urban areas, forests, protected areas etc.; (e) the sites appropriate for additional high-capacity treatment facilities, as laid out in the latest regional waste management plans of 2016. Based on the expected mortar production quantities $(\mathrm{t} / \mathrm{d})$ per region and dividing by the number of proposed plants per region, a production capacity for each plant was calculated (Table 6). Cost-related assumptions are based on [21,34].

Table 6. Mortar production capacities for six ZWMP plants.

\begin{tabular}{lccccc}
\hline \multicolumn{7}{c}{ Production Capacity (t/d) } \\
\hline Sindos & Mavrorachi & Ag. Antonios I & Ag. Antonios II & Kozani & Xanthi \\
\hline 623.75 & 623.75 & 623.75 & 623.75 & 306.79 & 722.21 \\
\hline
\end{tabular}

Investment costs analysis and production costs calculations were performed according to the methodology suggested by [35-37], and results are depicted in Tables 7 and 8.

Table 7. Analysis of investment costs in $(€)$ for ZWMP plants.

\begin{tabular}{lccccc}
\hline \multicolumn{1}{c}{ Investment } & Sindos & Mavrorachi & Ag. Antonios ${ }^{1}$ & Kozani & Xanthi \\
\hline Rotary kiln & $1,888,849$ & $2,002,600$ & $4,003,075$ & 982,829 & $2,304,056$ \\
\hline MSW transportation and treatment & $1,766,232$ & 600,912 & 733,209 & 714,895 & $2,129,547$ \\
\hline Raw materials transportation and treatment & $1,637,814$ & $1,637,814$ & $3,273,890$ & 803,800 & $1,884,358$ \\
\hline Land cost and yard improvement & 182,392 & 182,392 & 364,784 & 89,514 & 209,849 \\
\hline Service facilities & $1,091,876$ & $1,091,876$ & $2,183,752$ & 535,867 & $1,256,238$ \\
\hline Storing and product transportation & 910,724 & 910,724 & $1,821,448$ & 446,961 & $1,047,817$ \\
\hline Electrical installations & $1,456,662$ & $1,456,662$ & $2,913,324$ & 714,895 & $1,675,936$ \\
\hline Buildings (including services) & $2,184,993$ & $2,184,993$ & $4,369,986$ & $1,072,343$ & $2,513,904$ \\
\hline Engineering and supervision & $1,091,876$ & $1,091,876$ & $2,183,752$ & 535,867 & $1,256,238$ \\
\hline Emissions control system & $3,641,656$ & $3,641,656$ & $7,283,312$ & $1,787,238$ & $4,189,841$ \\
\hline Laboratory & 364,786 & 364,786 & 729,572 & 179,028 & 419,698 \\
\hline Other costs & 364,786 & 364,786 & 729,572 & 179,028 & 419,698 \\
\hline Total capital investment per plant & $16,582,586$ & $15,531,077$ & $30,589,676$ & $8,042,265$ & $17,174,633$ \\
\hline
\end{tabular}

Note: Costs are based on machine manufacturers offers, on local transportation prices and other local costs. ${ }^{1}$ Plants Ag. Antonios I and Ag. Antonios II combined. 
Table 8. Operating cost estimations. Analysis per year in $(€)^{1}$ of the ZWMP plants of Sindos, Mavrorachi, Ag. Antonios I/II. Kozani and Xanthi.

\begin{tabular}{|c|c|c|c|c|c|}
\hline A Direct Production Cost & Sindos & Mavrorachi & Ag. Antonios ${ }^{2}$ & Kozani & Xanthi \\
\hline Raw materials and transportation & $1,183,692$ & $1,183,692$ & $2,367,384$ & 580,928 & $1,361,877$ \\
\hline Labor and supervision & 818,907 & 818,907 & $1,637,814$ & 401,900 & 942,179 \\
\hline Diesel & 91,817 & 91,817 & 183,632 & 45,061 & 105,638 \\
\hline Pet coke & 545,937 & 545,937 & $1,091,867$ & 267,993 & 628,119 \\
\hline Product packaging & 436,750 & 436,750 & 873,493 & 214,346 & 502,495 \\
\hline Total A & $4,187,590$ & $4,187,590$ & $8,375,155$ & $2,055,228$ & $4,817,958$ \\
\hline \multicolumn{6}{|l|}{ B Fixed Charges } \\
\hline Depreciation ( $10 \%$ of the capital investment) & $1,658,258$ & $1,553,107$ & $3,057,769$ & 804,227 & $1,930,718$ \\
\hline \multicolumn{6}{|l|}{ C Overhead costs } \\
\hline Administrative costs-R\&D & 245,671 & 245,671 & 491,340 & 120,570 & 282,653 \\
\hline Marketing & 272,968 & 272,968 & 545,933 & 133,966 & 314,059 \\
\hline Total C & 518,640 & 518,640 & $1,037,273$ & 254,536 & 596,712 \\
\hline Total Annual Operating Cost $(\mathrm{A}+\mathrm{B}+\mathrm{C})$ & $6,698,414$ & $6,569,957$ & $13,081,751$ & $3,274,835$ & $7,731,530$ \\
\hline Mortar Production (t/d) & 623.75 & 623.75 & 1247.5 & 306.79 & 722.21 \\
\hline Mortar Production (t/y) & $218,312.5$ & $218,312.5$ & 436,625 & 107,376 & 252,773 \\
\hline Product cost per $t$ approximately & 30.68 & 30.09 & 29.96 & 30.49 & 30.58 \\
\hline Gross annual income from mortar sales $(€ / y)=\mathrm{t} / \mathrm{y} \times 55 € / \mathrm{t}^{3}$ & $12,007,187$ & $1,2007,187$ & $24,014,375$ & $5,905,680$ & $13,902,515$ \\
\hline
\end{tabular}

${ }^{1}$ Rounded to euro. ${ }^{2}$ Plants Ag. Antonios I and Ag. Antonios II combined. ${ }^{3}$ The wholesale price of $55 € / t$ is considered to be very competitive. ${ }^{4}$ Today taxes in Greece for S.A (Anonymous Societies) is $29 \%$ of profit.

\section{Results and Discussion}

The raw materials (including MSW-derived ash) that are needed for daily mortar production are given in Table 4.

For the production of $500 \mathrm{t} /$ day of mortar, $100 \mathrm{t} /$ day ash is required. Based on that, the ash produced from ZWMP and the quantities of mortar that can be achieved in each region are provided in Table 5.

The selected areas for ZWMP plants establishment are depicted in Figure 1. In Central Macedonia, four plants are envisaged based on the following criteria: One in the proximity of the SL of Mavrorachi, the largest SL in Central Macedonia with a total capacity of 14,900,000 $\mathrm{m}^{3}$ [29]. In the aforementioned MSW management plan [29], it is mentioned that a facility of "mechanical-biological treatment \& thermal treatment" (Integrated Facility of Processing and Disposal of Waste, IFPDW), $30 \mathrm{~km}$ from the Mavrorachi SL had been granted a positive Preliminary Environmental Impact Assessment under the Greek Law, and a Public Private Partnership (PPP) was sought. However, until 2011, no contractor was awarded. Therefore, this siting was chosen for the first Central Macedonia plant. A second IFPDW is suggested in the municipality of Ag. Antonios that is found $6.5 \mathrm{~km}$ southeastern of the rehabilitated WDS of Tagarades. This facility is envisaged to contain a mechanical/biological sorting facility, a biogas and secondary gas power plant, a novel SL for residual waste and a hazardous waste SL. A positive Preliminary Environmental Impact Assessment (PEIA) under the Greek Law for the siting was granted in 2008 and an Environmental Assessment Approval was also granted for the technologies of anaerobic digestion/aerobic biological drying applied in the facility. This site was also chosen for the siting of the second and the third Central Macedonia plant, since a positive PEIA for solid waste management facilities exists. Furthermore, the siting is ideal for the majority of the solid 
waste produced; all other SL (with the exception of Palaiokastro) have a 100-fold lower capacity than the Mavrorachi facility in Thessaloniki that is going to be partially alleviated by the Agios Antonios IFPDW. The last plant siting has been chosen to be within the industrial estate of Sindos, an area zoned and planned for the purpose of the industrial development of Thessaloniki, which is provided with good transportation access. Regarding the region of Western Macedonia, a siting in the proximity of the SL of Kozani is proposed, since this area is considered seminal in the latest waste management plan and is also able to host additional waste management facilities [30]. In Eastern Macedonia and Thrace, one plant close to SL of Xanthi is proposed, which is the largest SL of the prefecture (total capacity of $500,000 \mathrm{~m}^{3}$ ) [32]. The sitings have considered the NIMBY syndrome (it is expected to be lessened in sites already enrolled in industrial activities and in MSW management activities and in sites found legislatively fit for MSW management activities). It should be highlighted that public acceptability is quite important in implementing waste management schemes, as shown in similar projects in EU [38], and the intensity of the opposition to the scheme is usually dependent on the concern level of the pre-existing general environment [39]. As such, public concern in these sitings is expected to be low.

The calculated mortar production capacities of the five plants of Northern Greece are given in Table 6.

The investment cost of the ZWMP plants of Sindos, Mavrorachi, Kozani and Xanthi are given in Table 7, and the corresponding operating cost per year in Table 8.

As such, the total capital investment cost per plant in $€$ is $16,582,586,15,531,077,30,589,676$, 8,042,265 and 17,174,633 for the six plants of Sindos, Mavrorachi, Ag. Antonios I and II, Kozani and Xanthi, respectively.

The cost investment for all the six ZWMP plants of the three regions of North Greece (Central Macedonia, Western Macedonia, Eastern Macedonia and Thrace) is $87,920,237 €$. Usually, EU funding supports the construction of such plants covering a part of the investment cost.

The annual total operating cost per plant (Table 8) was calculated to be $6,698,414,6,569,957$, $13,081,751,3,274,835$ and 7,731,530€ for the six plants of Sindos, Mavrorachi, Ag. Antonios I and II, Kozani and Xanthi, respectively. This estimation takes into account the cost of the ingredients, as well as maintenance, fuel, packaging, working personnel and administration personnel cost.

The overall annual operating cost for all the six ZWMP plants of the three regions of North Greece (Central Macedonia, Western Macedonia, Eastern Macedonia and Thrace is 37,356,487€. Based on the above data, the total cost of production for the MSW-containing mortar was estimated to be roughly 29-30 $€ /$ t. Considering an ex-works mortar wholesale price of $55 € / t$, an annual gross income before taxes of 30,480,457€ and net profit/y of approximately 21,641,132€ for all the six ZWMP plants of the three regions of North Greece (Central Macedonia, Western Macedonia, Eastern Macedonia and Thrace) was estimated.

The results derived from this study suggest that the management of MSW of North Greece through the ZWMP method is profitable while, in general, this method is considered environmentally friendly [21].

Due to the economic crisis in Greece, reconstruction and construction works in general have been negatively impacted; however, there is still room for construction opportunities and especially renovations. Nevertheless, a critical shift in the prioritization of construction works is slowly taking place; as depicted by relevant research, the main forces of shift towards sustainable construction in Greece were energy saving and resources utilization, stricter land use regulations and efficient urban planning policies [40]. As such, a circular economy scheme that utilizes waste from one industry as initial material for another falls well within the concept of sustainable construction works.

The overall production of the six ZWMP plants in North Greece was calculated to be $3524 \mathrm{t} / \mathrm{d}$. This is above the estimated today's demand of Northern Greece. Nevertheless, since today's price of such products in Greece ranges between 90 to above $120 € / t$, [41] the ex-works wholesale price of $55 € / t$ is highly conservative and extremely attractive not only for Greece but also for many other countries. The price of $55 € / t$ is highly competitive for the East Mediterranean area and Middle East markets. 
Various ports (Thessaloniki, Kavala and Alexandroupoli) are relatively close to the plants and this may aid access to international markets. Furthermore, the estimated production cost of the product in the proposed plant units is competitive in relation to other mortar-producing plants in Greece.

It should be also taken into account that the full operational cost of a sanitary landfill in Greece is approximately $45 € / t$ [42]. High deviation was noted, but the average value was much higher than the EU estimates for Greek SL. Furthermore, no depreciation of the investment costs happens for existing landfills operating beyond their design lives. This value is above the product cost per ton of a ZWMP plant. Furthermore, since each individual plant is profitable separately, priority can be given to the construction of the most promising ZWMP plants, which will be relatively close to big cities, harbors and railway networks and close to limestone deposits, which exist in abundance in various sites in Greece and the Mediterranean area.

Finally, although the results were based on data focusing on Greece, the ZWMP approach should be considered in similar cases for other countries, especially in the Mediterranean Basin, Africa and Asia and elsewhere, where financially appropriate (mortar cost, availability and cost or raw materials, personnel cost etc.).

\section{Conclusions}

Nowadays, European Regulation prioritizes the substantial decrease of terminal waste that cannot offer material recuperation and/or energy generation. Landfilling cannot exploit the intrinsic qualities of waste, however it is the main management option in Greece. It is evident that this is not a viable option, as shown by its non-satisfactory environmental performance. The present research demonstrates that the application of the ZWMP method instead is a feasible and profitable alternative for MSW management, rendering a competitive mortar production cost of $\sim 29-30 € / t$ when the construction-operating cost for a sanitary landfill reaches $\sim 45 € / t$. These results were based on MSW production in Central Macedonia, Western Macedonia, Eastern Macedonia and Thrace in Northern Greece, using realistic data, i.e., only municipal solid waste production, excluding all separately collected recyclable materials, taking into account modest MSW increases. Comparison of the estimated production cost with the actual market prices confirms the viability of ZWMP plants in Greece. Furthermore, it is suggested that this work can also be applied to regions or countries with similar characteristics to those of the Northern Greece regions.

Author Contributions: Conceptualization, methodology development by A.S.; data manipulation, draft preparation and correction by C.E.

Funding: This research received no external funding.

Acknowledgments: The authors wish to express their kind acknowledgements to C. Sikalidis for offering access and use of the Laboratory of Industrial Inorganic Raw Materials, in the Chemical Engineering Department of the Aristotle University of Thessaloniki.

Conflicts of Interest: The authors declare no conflict of interest.

\section{References}

1. Communication from the commission to the European parliament, the council, the European economic and social committee and the committee of the regions-Roadmap to a resource efficient Europe. Available online: http://eur-lex.europa.eu/legal-content/EN/TXT/?uri=CELEX:52011DC0571 (accessed on 15 July 2019).

2. EC Directives. Directive 2008/98/EC of the European Parliament and of the Council of 19 November 2008 on waste and repealing certain Directives. Off. J. Eur. Union 2008, 34, 3-30.

3. Directive, Landfill. Council Directive 1999/31/EC of 26 April 1999 on the landfill of waste. Off. J. Eur. Commun. 1999, 182, 1-19.

4. European Environment Agency. Report No 2-Managing Municipal Solid Waste; Publications Office of the European Union: rue Mercier, Luxembourg, 2013. 
5. Pradel, M.; Aissani, L.; Villot, J.; Baudez, J.C.; Laforest, V. From waste to added value product: Towards a paradigm shift in life cycle assessment applied to wastewater sludge-A review. J. Clean. Prod. 2016, 131, 60-75. [CrossRef]

6. Lazoglou, K.; Widmar, R.; Vatseris, C.; Papadopoulos, S. An Overview of the Current Situation Regarding the Management and Composition of MSW of East Macedonia and Thrace Region; Greece INTERGEO Environmental Technology Ltd.: Thessaloniki, Greece, 2007. (In Greek)

7. Botetzagias, I.; Dima, A.-F.; Malesios, C. Extending the Theory of Planned Behavior in the context of recycling: The role of moral norms and of demographic predictors. Resour. Conserv. Recyl. 2015, 95, 58-67. [CrossRef]

8. HERRCO. Available online: http://www.herrco.gr/ (accessed on 15 July 2019).

9. Theodorou, P.; Vratsanou, K.C.; Botzori, M.; Skanavis, C. Recycling and education through digital storytelling in the age group "8-12" in Greece. In Proceedings of the Protection and Restoration of the Environment XIV, Thessaloniki, Greek, 3-6 July 2018; pp. 229-239.

10. Andreasi Bassi, S.; Christensen, T.H.; Damgaard, A. Environmental performance of household waste management in Europe-An example of 7 countries. Waste Manag. 2017, 69, 545-557. [CrossRef] [PubMed]

11. Tchobanoglous, G.; Theisen, H.; Vigil, S. Integrated Solid Waste Management; McGraw Hill: New York, NY, USA, 1993.

12. Koufodimos, G.; Samaras, Z. Waste management options in southern Europe using field and experimental data. Waste Manag. 2000, 22, 47-59. [CrossRef]

13. Ali, M.T.; Chang, W.F. Strength properties of cement-stabilized municipal solid waste incinerator ash masonry bricks. ACI Mater. J. 1994, 91, 256-263.

14. Yakubu, Y.; Zhou, J.; Shu, Z.; Tan, Y.; Zhao, Z.; Mbululo, Y. Potential industrial utilization of pre-treated municipal solid waste incineration fly ash. Waste Manag. Res. 2018, 36, 635-644. [CrossRef] [PubMed]

15. Kikuchi, R. Recycling of municipal solid waste for cement production: Pilot-scale test for transforming incineration ash of solid waste into cement clinker. Resour. Conserv. Recyl. 2001, 31, 137-147. [CrossRef]

16. Chatziaras, N.; Psomopoulos, C.S.; Themelis, N.J. Use of waste derived fuels in cement industry: A review. Manag. Environ. Qual. Int. J. 2016, 27, 178-193. [CrossRef]

17. European Environment Agency. Waste Generation and Management_Environment in EU at the Turn of Century; European Environment Agency Press: Copenhagen, Denmark, 1999; pp. 212-213.

18. Kurda, R.; Silvestre, J.D.; de Brito, J. Toxicity and environmental and economic performance of fly ash and recycled concrete aggregates use in concrete: A review. Heliyon 2018, 23, e00611. [CrossRef] [PubMed]

19. Karayannis, V.G.; Karapanagioti, H.K.; Domopoulou, A.E.; Komilis, D.P. Stabilization/Solidification of Hazardous Metals from Solid Wastes into Ceramics. Waste Biomass Valorization 2017, 8, 1863-1874. [CrossRef]

20. Sikalidis, C.; Tanis, C.; Famellos, S. Method for solid wastes utilisation by means of thermal co-processing with mineral raw materials for the production of a widely applicable mortar. Greek Patent No 1003333, 7-3-2000-Intern. Cl. CO4B 7/24, CO4B 7/44, 2000.

21. Sikalidis, C.; Zabaniotou, A.A.; Famellos, S.P. Utilisation of municipal solid wastes for mortar production. Resour. Conserv. Recycl. 2002, 36, 155-167. [CrossRef]

22. Psomopoulos, C.S.; Stavroulakis, C.; Vasilios, S.; Themelis, N.J. Greenhouse gases emission reduction potential in Greece by implementing WTE facilities in strategically selected urban areas. Fresenius Environ. Bull. 2013, 22, 2042-2047.

23. Yannopoulos, N.; Dimoudi, E.; Plakas, K. Management of MSW in Prefecture of Thessaloniki; Technical Chamber of Greece: Thessaloniki, Greece, 2010. (In Greek)

24. Eurostat. Municipal Waste Statistics. Available online: https://ec.europa.eu/eurostat/statistics-explained/ index.php?title=Municipal_waste_statistics (accessed on 2 July 2019).

25. Ministry of Environment and Energy. Available online: http://www.ypeka.gr/?tabid=438 (accessed on 2 July 2019). (In Greek)

26. Perkoulidis, G.; Papageorgiou, A.; Karagiannidis, A.; Kalogirou, S. Integrated assessment of a new Waste-to-Energy facility in Central Greece in the context of regional perspectives. Waste Manag. 2010, 30, 1395-1406. [CrossRef] [PubMed] 
27. Revision of the National Waste Management Plan: State of the Art and Evaluation of the State of the Art: 2nd Deliverable-for Consultation; In Revision of the National Waste Management Plan: State of the Art and Evaluation of the State of the Art: 2nd Deliverable-for Consultation; Ministry of Environment and Energy: Athens, Greece, 2013. (In Greek)

28. Hellenic Statistical Authority. Available online: http://www.statistics.gr/el/statistics/-/publication/SOP06/ (accessed on 2 July 2019). (In Greek).

29. Fodsa, K.M. Review of Regional Waste Management Plan of Central Macedonia and Strategic Environmental Impact Assessment; Regional Association of Organizations of Waste Management of Central Macedonia (FODSA KM): Thessaloniki, Greece, 2016. (In Greek)

30. DIADYMA. Regional Waste Management Plan of West Macedonia; Waste Management of West Macedonia, S.A. (DIADYMA): Kozani, Greece, 2016. (In Greek)

31. Athanasiou, C.J.; Tsalkidis, D.A.; Kalogirou, E.; Voudrias, E.A. Feasibility analysis of municipal solid waste mass burning in the Region of East Macedonia-Thrace in Greece. Waste Manag. Res. 2015, 33, 561-569. [CrossRef] [PubMed]

32. DIAAMATH. Update of Regional Waste Management Plan of the Prefecture of Eastern Macedonia and Thrace; Organization of Waste Management of Eastern Macedonia and Thrace (DIAAMATH): Komotini, Greece, 2016. (In Greek)

33. Takacs, L.; Moilanen, G.L. Simultaneous control of PCDD/PCDF, $\mathrm{HCl}$ and NOx emissions from municipal solid waste incinerators with ammonia injection. J. Air. Waste Manag. Assoc. 1990, 41, 716-722. [CrossRef]

34. Tsiligakis, S. MSW management through zero waste technology for mortar production in central macedonia and thrace. Undergraduate Dissertation Thesis, Department of Chemical Engineering, Aristotle University of Thessaloniki, Thessaloniki, Greece, 2016. (In Greek).

35. Greek Industrial Development Bank. S.A. Handbook of Evaluation of Investment Plants; Directorate of Studies: Athens, Greek, 1985. (In Greek)

36. Bhimani, A.; Horngren, C.T.; Datar, S.M.; Rajan, M.V. Management and Cost Accounting; Pearson Education Limited: Essex, UK, 2012.

37. European Commission. Guide to Cost-Benefit Analysis of Investment Projects; Directorate-General for Regional and Urban Policy: Brussels, Belgium, 2015.

38. Kikuchi, R.; Gerardo, R. More than a decade of conflict between hazardous waste management and public resistance: A case study of NIMBY syndrome in Souselas (Portugal). J. Hazard. Mater. 2009, 172, 1681-1685. [CrossRef] [PubMed]

39. Slovic, P.; Fischhoff, B.; Lichtenstein, S. Facts and Fears-Understanding Perceived Risk. In Societal Risk Assessment-How Safe Is Safe Enough? Schwing, R.C., Albers, W.A., Eds.; Plenum Press: New York, NY, USA, 1980.

40. Manoliadis, O.; Tsolas, I.; Nakou, A. Sustainable construction and drivers of change in Greece: A Delphi study. Construct. Manag. Econ. 2006, 24, 113-120. [CrossRef]

41. Heracles Cement Co. Available online: https://www.kaxirismonotika.gr/-tsimento-.html (accessed on 2 July 2019). (In Greek).

42. Komilis, D.; Liogkas, V. Full cost accounting on existing and future municipal solid waste management facilities in Greece. Glob. NEST J. 2014, 16, 787-796. [CrossRef]

(C) 2019 by the authors. Licensee MDPI, Basel, Switzerland. This article is an open access article distributed under the terms and conditions of the Creative Commons Attribution (CC BY) license (http://creativecommons.org/licenses/by/4.0/). 